dr inż. Marek Sobaś

Instytut Pojazdów Szynowych „TABOR”

\title{
Zabiegi technologiczne zwiększające prognozowaną żywotność osi zestawów kolowych
}

\begin{abstract}
$W$ artykule przedstawiono środki technologiczne zwiększajace żywotność osi zestawów kołowych $w$ układach biegowych tocznych oraz napędnych układów biegowych pojazdów trakcyjnych. Istotny wktad $w$ zakresie rozwoju kryteriów technologicznych $i$ badań odbiorczych osi zestawów kołowych wnosi nowa norma PN-EN 13261:2009. Przedstawiono porównanie tych kryteriów z dotychczas obowiqzujacymi przepisami UIC oraz krajowymi. Artykut zostat opracowany w ramach projektu badawczo-

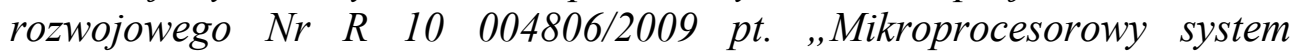
diagnostyczny głównych systemów trakcyjnego pojazdu szynowego uwzględniajacy ocenę bieżaca i prognozowanie stanów”, finansowanego $z$ budżetu Ministerstwa Nauki i Szkolnictwa Wyższego.
\end{abstract}

\section{Wstęp}

Problematyka związana z rozwojem technologii wytwarzania osi zestawów kołowych jest wciąż aktualna. Rozwój tej technologii jest wynikiem wzrastających parametrów eksploatacyjnych, jakie muszą spełniać obecne pojazdy. Do podstawowych parametrów technicznych pojazdów, podlegającym zwiększeniu należą miedzy innymi prędkość oraz nacisk zestawu kołowego na tor. Zwiększenie tych parametrów jest wywołane wzrastającymi wymaganiami, stawianymi przez przewoźników kolejowych, w wyniku konkurencji na rynku transportowym. Oś zestawu kołowego nabiera więc jako element konstrukcyjny coraz większego znaczenia, decydującego o bezpieczeństwie eksploatacyjnym pojazdu trakcyjnego. Tym należy tłumaczyć coraz większy nacisk na rozwój:

- metod obliczeniowych, przedstawionych w PN-EN 13103:2009 [15] oraz PN-EN 13104:2009 [16] oraz w $[4,19]$,

- metod diagnostycznych $[1,3,8,9,11,12,14,20]$ oraz

- prognozowania pęknięć w osiach zestawów kołowych $[5,8,10]$.

Niewątpliwie do zwiększenia żywotności osi przyczynia się również technologia wykonania osi, która ma ostateczny wpływ na osiagnięcie zakładanej granicy zmęczenia materiału. Norma PN-EN 13261:2009 [17] przedstawia wymagania technologiczne $\mathrm{w}$ następujących zakresach:

- składu chemicznego

- dopuszczalnych wad mikrograficznych

- wymagań wytrzymałościowych

- zabezpieczeń antykorozyjnych

- dopuszczalnych naprężeń własnych.
2. Skład chemiczny oraz wymagania wytrzymałościowe

\subsection{Skład chemiczny}

Jednym $\mathrm{z}$ istotnych czynników mających wpływ na własności wytrzymałościowe jest zawartość pierwiastków uznanych jako szkodliwe. Zgodnie z PN-EN 13261:2009 [17] skład chemiczny stali użytych na wykonanie osi zestawów kołowych tzn. EA1N, EA1T oraz EA4T (stal 25Cr Mo4) jest przedstawiony w tabeli 1 .

Do pierwiastków uznanych za szkodliwe można zaliczyć siarkę i fosfor. Segregacje fosforu są jedną z głównych przyczyn struktury pasmowej w wyrobach walcowanych, a poza tym powodują większą kruchość stali, niż można by przewidywać $z$ przeciętnej zawartości fosforu. Nawet w granicach dopuszczalnych zawartości fosfor zwiększa skłonność do kruchości odpuszczania, zwłaszcza w stalach manganowych i chromowo-manganowych. Główną przyczyną dla której uważa się siarkę za pierwiastek szkodliwy jest kruchość na gorąco, którą wywołuje. Siarka ma znacznie mniejszą rozpuszczalność niż fosfor, co powoduje że wpływ siarki polega przede wszystkim na oddziaływaniu wtrąceń siarczkowych w fazę metaliczną. Ich zawartość została ograniczona odpowiednio do $0,025 \%$ oraz $0,015 \%$. Dla porównania skład chemiczny stali A1(C35e), A2(22MnCrV5), A3(C45e), A4(25Cr Mo4) i A5(42CrMo4) wg karty UIC 811-1 [13] jest przedstawiony w tabeli 2 . 


\begin{tabular}{|l|c|c|c|c|c|c|c|c|c|c|}
\hline \multirow{2}{*}{$\begin{array}{l}\text { Gat. } \\
\text { stali }\end{array}$} & $\mathbf{C}$ & $\mathbf{S i}$ & $\mathbf{M n}$ & $\mathbf{P}$ & $\mathbf{S}$ & $\mathbf{C r}$ & $\mathbf{C u}$ & Mo & Ni & V \\
\cline { 2 - 11 } & \multicolumn{8}{|c|}{ Zawartość procentowa pierwiastków } \\
\hline EA1N & 0,40 & 0,50 & 1,20 & 0,020 & 0,020 & 0,30 & 0,30 & 0,08 & 0,30 & 0,06 \\
\hline EA1T & 0,40 & 0,50 & 1,20 & 0,020 & 0,015 & 0,30 & 0,30 & 0,08 & 0,30 & 0,06 \\
\hline EA4T & $0,22 \div 0,29$ & 0,40 & 0,80 & 0,020 & 0,015 & $0,90 \div 1,20$ & 0,30 & $0,15 \div 0,30$ & 0,30 & 0,06 \\
\hline
\end{tabular}

Skład chemiczny stali używanych na osie zestawów kołowych wg karty UIC 811-1 [13]

Tabela 2

\begin{tabular}{|c|c|c|c|c|c|c|c|c|c|c|c|}
\hline \multirow{2}{*}{$\begin{array}{c}\text { Gat. } \\
\text { stali }\end{array}$} & $\mathbf{9}$ & $\mathbf{S i}$ & $\mathbf{M n}$ & $\mathbf{P}$ & $\mathbf{S}$ & $\mathbf{C r}$ & $\mathbf{C u}$ & Mo & Ni & V \\
\hline A1 & 0,37 & $\leq 0,46$ & $\leq 1,12$ & $\leq 0,040$ & $\leq 0,040$ & $\leq 0,30$ & $\leq 0,30$ & $\leq 0,05$ & $\leq 0,30$ & $\leq 0,05$ \\
\hline A2 & $0,17 \div$ & $\leq, 27$ & $\leq 0,40$ & $\begin{array}{c}1,00 \\
\div 1,40\end{array}$ & $\leq 0,025$ & $\leq 0,030$ & $\begin{array}{c}0,20 \\
\div 0,70\end{array}$ & $\leq 0,25$ & $\leq 0,15$ & $\leq 0,30$ & $\begin{array}{c}0,05 \\
\div 0,15\end{array}$ \\
\hline A3 & $\begin{array}{c}0,42 \div \\
0,50\end{array}$ & $\begin{array}{c}0,15 \\
\div 0,40\end{array}$ & $\begin{array}{c}0,50 \\
\div 0,80\end{array}$ & $\leq 0,035$ & $\leq 0,035$ & $\leq 0,030$ & $\leq 0,30$ & $\leq 0,08$ & $\leq 0,30$ & $\leq 0,05$ \\
\hline A4 & $\begin{array}{c}0,22 \div \\
0,29\end{array}$ & $\begin{array}{c}0,15 \\
\div 0,40\end{array}$ & $\begin{array}{c}0,50 \\
\div 0,90\end{array}$ & $\leq 0,035$ & $\leq 0,035$ & $\begin{array}{c}0,90 \\
\div 1,20\end{array}$ & $\leq 0,30$ & $0,15 \div 0,30$ & $\leq 0,30$ & $\leq 0,05$ \\
\hline A5 & $\leq 45$ & $\leq 0,40$ & $\leq 0,90$ & $\leq 0,035$ & $\leq 0,035$ & $\leq 1,20$ & $\leq 0,30$ & $\leq 0,30$ & $\leq 0,30$ & $\leq 0,10$ \\
\hline
\end{tabular}

Jak widać z przedstawionego porównania zawartość siarki oraz fosforu $\mathrm{w}$ poszczególnych gatunkach stali wg PN-EN13261:2009 [17] jest znacznie mniejsza niż tych, wymienionych w karcie UIC 811-1 [13].

Kolejnym istotnym ograniczeniem jest obowiązek kontrolowania zawartości wodoru w stali. Dopuszczalna zawartość wodoru w stali musi być mniejsza:

- kategorii 1 (dla pojazdów przystosowanych do prędkości powyżej $200 \mathrm{~km} / \mathrm{h}$ ) od $2 \mathrm{ppm}$ oraz

- kategorii 2 (dla pojazdów przystosowanych do prędkości $\leq 200 \mathrm{~km} / \mathrm{h}$ ) od $2,5 \mathrm{ppm}$.

Norma PN-EN 13261:2009 (załącznik G) [17] zwiększyła znacznie wymagania dotyczące sprawdzenia zawartości wodoru w wytopie stali przeznaczonej na osie zestawu kołowego.

W celu usunięcia wodoru ze stali zaakceptowano dwie metody analizy:

- odgazowanie próżniowe w temperaturze $650 \div 1050^{\circ}$

- poprzez wdmuchiwanie lotnego gazu w ciekłą stal o temperaturze $650 \pm 20^{\circ} \mathrm{C}$; gaz zatrzymywany jest $\mathrm{w}$ drodze powrotnej, który zawiera wodór i jest odzyskiwany do obiegu.

Sprawdzenie zawartości wodoru w stali, przeznaczonej na osie zestawów kołowych odbywa się za pomocą pobierania próbek z wytopu jedną z czterech metod:

- metodą kokili miedziowych

- rury krzemowej

- rury wydmuchującej krzem (nie dopuszcza się stosowania kwarcu przepuszczającego światło)

- metodą próbki zanurzeniowej (metoda nośnego gazu z detektorem z przewodnością cieplna).
Wodór jest pierwiastkiem, którego zawartość w stali jest zdecydowanie szkodliwa. Wodór jest przyczyną powstawania kruchości w stali tzw. „kruchości wodorowej". Według jednej z hipotez wodór tworzy atmosfery dookoła dyslokacji. Przy względnie powolnym odkształceniu atmosfery te przemieszczają się wraz z dyslokacjami, skutkiem czego $\mathrm{w}$ takich miejscach powstają zarodki pęknięć, wodór wypełnia je, wytwarzając $\mathrm{w}$ nich skutkiem rekombinacji atomów w cząsteczki znaczne ciśnienie i w ten sposób ma ułatwiać pękanie. Niezależnie od wszystkich opisanych zjawisk, wodór może być przyczyną powstawania poważnych wad wyrobów stalowych, zwanych płatkami. Płatki występują przede wszystkim w strefach środkowych wyrobów o dużych przekrojach. $Z$ wyrobów cienkich znaczna cześć wodoru pochodzącego z procesu stalowniczego ulatnia się już podczas obróbki plastycznej, dzięki czemu nie powoduje uszkodzeń. Płatki są pęknięciami o wymiarach od kilku do kilkunastu milimetrów, zorientowanymi prostopadle do kierunku naprężeń własnych, powstającymi poniżej $200 \div 250^{\circ} \mathrm{C}$ podczas stygnięcia po przeróbce plastycznej, chociaż obserwowano również ich tworzenie się w ciągu kilkunastu dni po ostygnięciu. Płatki widoczne na przełomie stali stanowią jasne plamy, różniące się wielkością ziarna i połyskiem od reszty powierzchni przełomu. Szczególnie wyraźnie występują na przełomach stali hartowanych i odpuszczanych. Na szlifach stanowią zasadniczo krótsze lub dłuższe pęknięcia, czasami tak cienkie, że dopiero po trawieniu można je wyraźnie obserwować. W kontroli produkcji do wykrywania płatków stosuje się powszechnie badania ultradźwiękowe, tym bardziej że ich rozmieszczenie wewnątrz odkuwek czyni je tak 
cienkie, że dopiero po trawieniu można je wyraźnie obserwować. Przyczyną powstawania płatków jest wodór i naprężenia własne, zarówno cieplne jak i strukturalne. Występowanie płatków powoduje wodór zawarty $\mathrm{w}$ stali $\mathrm{w}$ wyniku procesu stalowniczego. Zawartość wodoru zależy w dużym stopniu od metody wytopów i warunków, w jakich jest prowadzony. Zgodnie z danymi literaturowymi można przytoczyć następujące dane:

- stal z kwaśnego pieca martenowskiego $3 \div 7$ $\mathrm{cm}^{3} / 100 \mathrm{~g}$

- stal z zasadowego pieca martenowskiego $4 \div 10 \mathrm{~cm}^{3} / 100 \mathrm{~g}$

- stal z zasadowego pieca elektrycznego $4 \div 8$ $\mathrm{cm}^{3} / 100 \mathrm{~g}$ [6].

Głównym czynnikiem określającym zawartość wodoru w stali jest ilość pary wodnej w atmosferze pieca. Z roztopionej stali w piecu wodór wydziela się szybciej, im bardziej energiczne jest świeżenie (tzw. gotowanie kapieli), lecz z chwilą przerwania świeżenia zawartość wodoru zaczyna wzrastać. Wodór może pochodzić ze zlasowanego wapna, nie wysuszonych żelazostopów i dodatków nawęglających do kadzi. Niedostatecznie wysuszona kadź i zbyt gruba warstwa lakieru na ściankach wlewnicy stanowią dalsze źródła wodoru przechodzącego do stali. W przypadkach niekorzystnych zawartość wodoru $\mathrm{w}$ stali może znacznie przekroczyć podane wyżej wartości. Wg jednej z hipotez zawartość wodoru wynosząca $2 \mathrm{~cm}^{3} / 100 \mathrm{~g}$ nie powodują powstawania płatków, nawet w największych przekrojach. Zawartość ta oczywiście zależy od gatunku stali, wielkości przekroju i warunków stygnięcia po przeróbce plastycznej na gorąco, dla małych przekrojów może być większa. Oprócz działania na własności mechaniczne wodór działa również chemicznie, reagując z niektórymi pierwiastkami w stali. Znane i wykorzystywane praktyczne jest silnie odwęglające działanie wilgotnego wodoru na stal podczas wyżarzania. Atmosfera wodoru umożliwia również usuwanie siarki, fosforu i tlenu $\mathrm{z}$ cienkich taśm stalowych podczas

Zestawienie dopuszczalnych wtrąceń dla stali kategorii 1 wg PN-EN 13261:2009 [17]

Tabela 3

\begin{tabular}{|c|c|c|c|c|}
\hline \multirow{2}{*}{ Typ wtrąceń } & \multicolumn{2}{|c|}{ Kategoria 1 } & \multicolumn{2}{c|}{ Kategoria 2 } \\
\cline { 2 - 5 } & $\begin{array}{c}\text { Seria wzrastająca } \\
\text { (maksimum) }\end{array}$ & $\begin{array}{c}\text { Seria malejąca } \\
\text { (maksimum) }\end{array}$ & $\begin{array}{c}\text { Seria wzrastająca } \\
\text { (maksimum) }\end{array}$ & $\begin{array}{c}\text { Seria malejąca } \\
\text { (maksimum) }\end{array}$ \\
\hline A (siarka) & 1,5 & 1,5 & 1,5 & 2 \\
\hline B(gliniany) & 1 & 1,5 & 1,5 & 2 \\
\hline C( krzemiany) & 1 & 1,5 & 1,5 & 2 \\
\hline D(tlenki ziarniste) & 1 & 1,5 & 1,5 & 3 \\
\hline B+C+D & 2 & 3 & 3 & 4 \\
\hline
\end{tabular}

Zestawienie własności wytrzymałościowych dla stali EA1N, EA1T oraz EA4T wg

PN-EN13261:2009 [17]

Tabela 4

\begin{tabular}{|c|c|c|c|c|c|}
\hline \multirow{3}{*}{ Gatunek stali } & $\mathbf{R}_{\mathbf{e H}}$ & $\mathbf{R m}$ & $\mathbf{A}_{\mathbf{5}}$ & $\begin{array}{c}\text { KU w kierun- } \\
\text { ku wzdlużnym }\end{array}$ & $\begin{array}{c}\text { KU w kierun- } \\
\text { ku poprzecz- } \\
\text { nym }\end{array}$ \\
\cline { 2 - 6 } & {$[\mathrm{MPa}]$} & {$[\mathrm{MPa}]$} & {$[\%]$} & {$[\mathrm{J}]$} & {$[\mathrm{J}]$} \\
\hline EA1N & $\geq 320$ & $550 \div 650$ & $\geq 22$ & $\geq 30$ & $\geq 20$ \\
\hline EA1T & $\geq 350$ & $550 \div 700$ & $\geq 24$ & $\geq 40$ & $\geq 25$ \\
\hline EA4T & $\geq 420$ & $650 \div 800$ & $\geq 18$ & $\geq 40$ & $\geq 25$ \\
\hline
\end{tabular}

Zestawienie własności wytrzymałościowych dla stali A1N, A1T, A2N, A3N, A3T, A4T oraz A5T wg karty UIC811-1 [13]

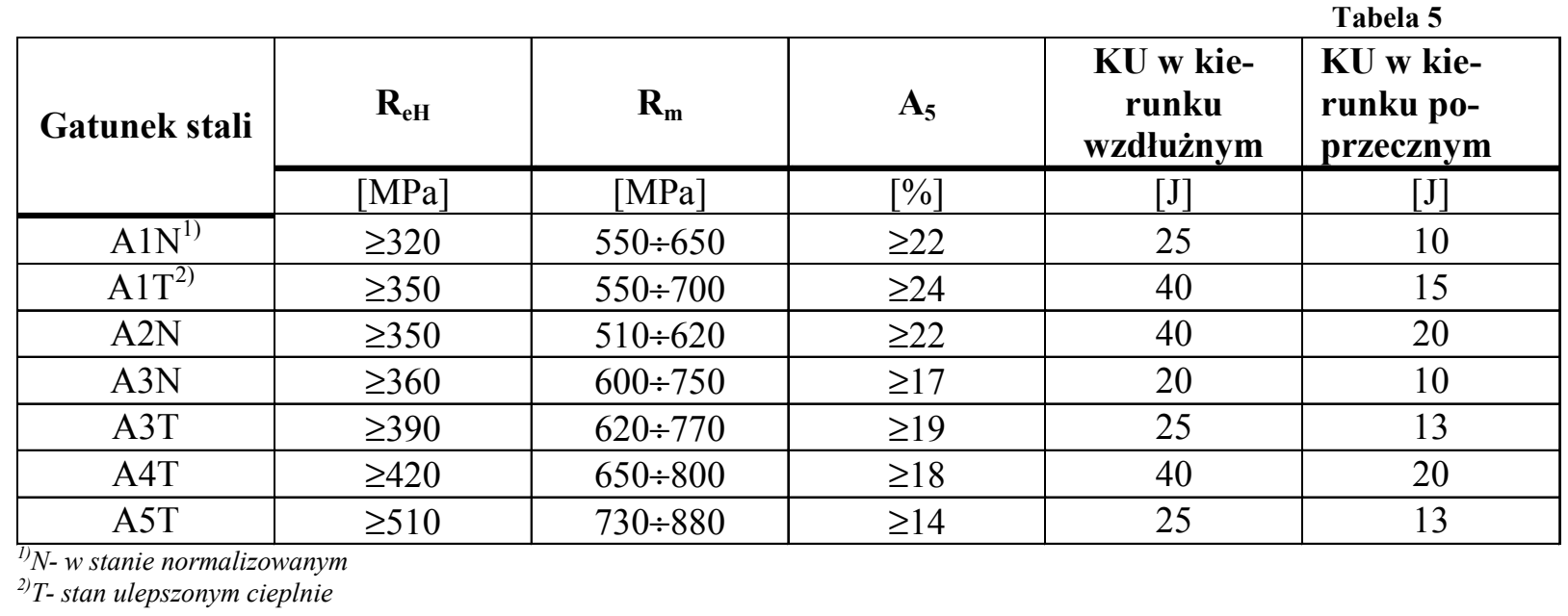


wyżarzania. W aparaturze syntezy związków wodorowych wodór pod dużym ciśnieniem działa na stal przy temperaturach dochodzących do $500^{\circ} \mathrm{C}$. W tych warunkach dyfundujący wodór reaguje $\mathrm{z}$ cementytem $\mathrm{i}$ rozkłada go, tworząc $\mathrm{z}$ węglem metan $\left(\mathrm{CH}_{4}\right)$, co powoduje poważne uszkodzenia struktury połączone $\mathrm{z}$ utratą wytrzymałości i ciągliwości. Zapobiega się temu, stosując stale stopowe, w których zamiast cementytu występują bardziej stabilne węgliki chromu, molibdenu, wolframu albo wanadu.

Kolejnym kryterium, które sformułowała norma PNEN 13261:2009 [17] było wprowadzenie dopuszczalnych wtrąceń, które są uznawane jako wady mikrograficzne i których rzeczywista wielkość jest sprawdzana za pomocą badań ultradźwiękowych. Poziomy dopuszczalnych wtrąceń dla stali przeznaczonych na osie kategorii 1 i 2 są przedstawione w tabeli 3.

\subsection{Wlasności wytrzymałościowe}

Własności wytrzymałościowe stali EA1N,EA1T oraz EA4T wg PN-EN 13261:2009 [17] są przedstawione w tabeli 4.

Jak widać z przedstawionego porównania własności wytrzymałościowe stali EA1N,EA1T oraz EA4T są zbliżone do stali A1N,A1T oraz A4T za wyjątkiem udarności. Zgodnie z PN-EN 13261:2009 [17] udarność dla stali EA1N, EA1T oraz EA4T jest nieco wyższa niż jej dawne odpowiedniki wg karty UIC 811-1 [13].

Zwraca się uwagę na fakt, że norma PNEN13261:2009 [17] zwiększyła wymagania w stosunku do karty UIC 811-1 w zakresie pomiarów wytrzymałościowych próbek. Próbki do badań wytrzymałościowych powinny być pobrane $\mathrm{w}$ trzech miejscach największego przekroju osi:

- możliwie blisko powierzchni zewnętrznych wszystkich osi

- w środku promienia i w osi symetrii pełnych osi

- w środku pomiędzy powierzchnią zewnętrzną i wewnętrzną w pobliżu wewnętrznej powierzchni osi drążonych.

Przykładowe rozmieszczenie próbek do badań wytrzymałościowych dla osi pełnych jest przedstawione na rys. 1 .
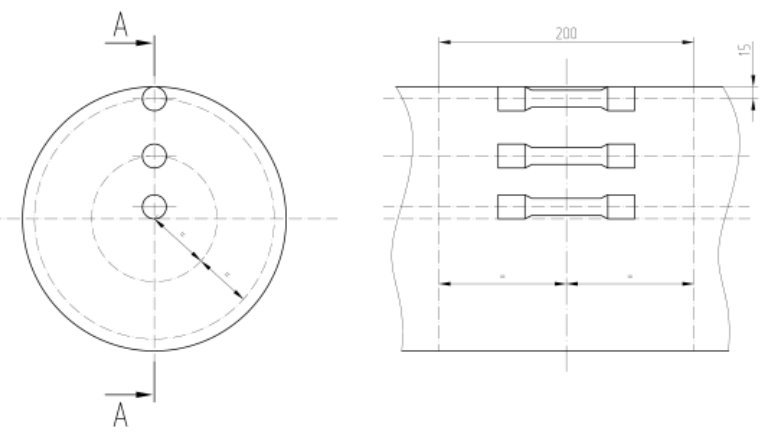

Rys.1. Rozmieszczenie próbek do przeprowadzenia prób rozciągania dla osi pełnych wg PN-EN 13261:2009 [17]

Rozmieszczenie próbek do badań wytrzymałościowych dla osi drążonych jest przedstawione na rys.2.

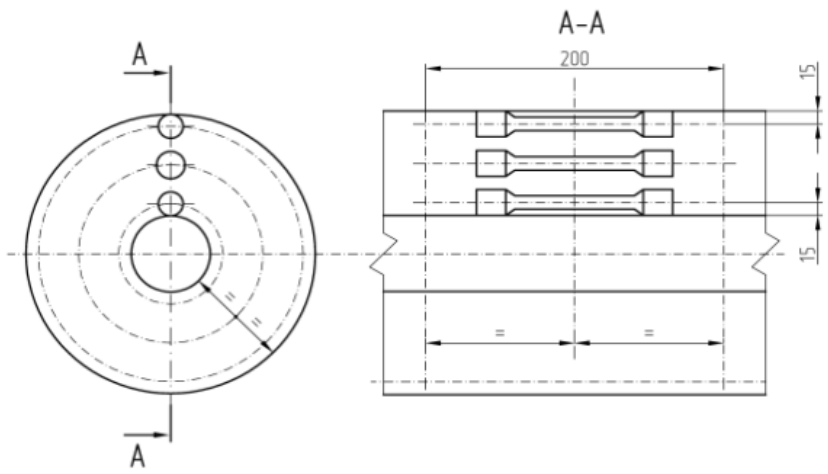

Rys.2. Rozmieszczenie próbek do przeprowadzenia prób rozciagania dla osi drążonych wg PN-EN 13261:2009 [17]

Wartości mierzone dla próbek pobieranych w pobliżu zewnętrznej powierzchni powinny być większe lub równe 0,95 wartości, mierzonej na połowie promienia osi lub w środku pomiędzy powierzchnią zewnętrzną lub wewnętrzną dla osi drążonych.

Dopuszczalne wartości w środku osi lub w pobliżu powierzchni otworu osi drążonych, muszą być większe lub równe 0,8 wartości mierzonej w połowie promienia pełnych osi lub $\mathrm{w}$ środku pomiędzy powierzchnią zewnętrzną i wewnętrzną osi drążonych. Rozmieszczenie próbek do badań udarności dla osi pełnych oraz drążonych jest przedstawione odpowiednio na rys.3 i rys. 4.

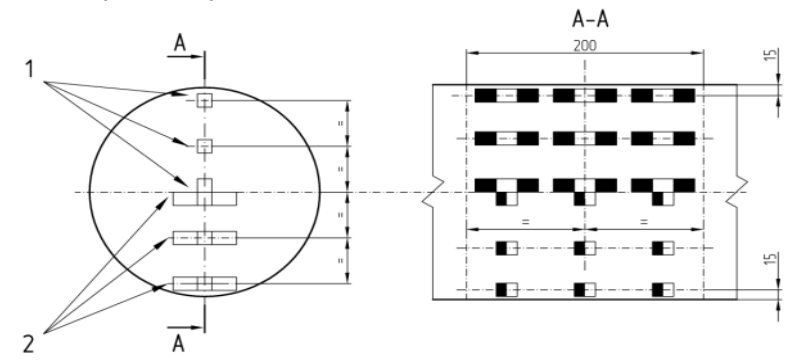

Legenda:

1 - próbki do badań w kierunku wzdtużnym

2 - próbki do badań w kierunku poprzecznym

Rys.3. Rozmieszczenie próbek do przeprowadzenia prób udarności dla osi pełnych wg PN-EN 13261:2009 [17]

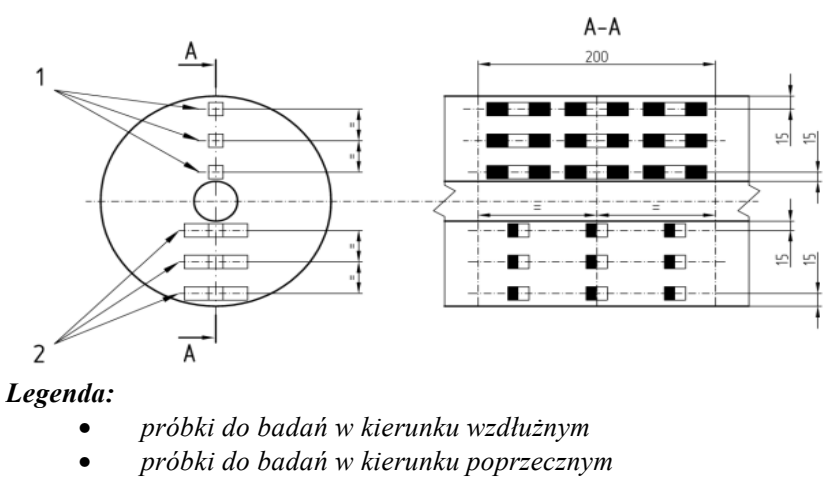

Rys.4. Rozmieszczenie próbek do przeprowadzenia prób udarności dla osi drążonych wg PN-EN 13261:2009 [17] 
Wartości udarności dla próbek osi, mierzonych w kierunku poprzecznym i wzdłużnym wg PN-EN 13261: 2009 [17]

Tabela 6

\begin{tabular}{|c|c|c|}
\hline $\begin{array}{c}\text { Gatunek } \\
\text { stali }\end{array}$ & $\begin{array}{c}\text { KU w kierunku } \\
\text { wzdłużnym [J] }\end{array}$ & $\begin{array}{c}\text { KU w kierunku } \\
\text { poprzecznym [J] }\end{array}$ \\
\hline EA1N & $\geq 30$ & $\geq 20$ \\
\hline EA1T & $\geq 40$ & $\geq 25$ \\
\hline EA4T & $\geq 40$ & $\geq 25$ \\
\hline
\end{tabular}

W pobliżu powierzchni zewnętrznej wartości udarności powinny być większe lub równe 0,95 wartości mierzonej $\mathrm{w}$ połowie promienia przy pełnych osiach lub wartości w środku pomiędzy powierzchnią zewnętrzną i wewnętrzną osi drążonych. Wartość mierzona $\mathrm{w}$ osi środkowej pełnych osi zestawów kołowych lub w pobliżu powierzchni otworu osi drążonych powinny wynosić więcej niż 0,8 wartości mierzonej w połowie promienia. Jak widać własności mechaniczne dla stali, użytej na osie zestawów kołowych są bardzo dokładnie badane. Tak dobrane stale pod względem składu chemicznego oraz własności wytrzymałościowych powinny zagwarantować własności zmęczeniowe, które są badane:

- na małych próbkach z gładkimi powierzchniami (granica wytrzymałości zmęczeniowej $\left.\mathrm{R}_{\mathrm{fL}}\right)$

- na małych próbkach z karbami (granica wytrzymałości zmęczeniowej $\mathrm{R}_{\mathrm{fE}}$ )

- na próbkach w skali 1:1 (granica wytrzymałości zmęczeniowej $F_{1}$ i $_{2}$,gdzie $F_{1}$ jest granicą zmęczenia dla stref próbki bez karbu, natomiast $F_{2}$ jest granicą zmęczenia dla próbek $\mathrm{z}$ karbem).

Poszczególne granice zmęczenia dla gatunków stali EA1N, EA1T oraz EA4T są przedstawione w tabeli 7. Zagwarantowane granice zmęczenia wg PN-EN 13261:2009 pozwalają na przyjęcie dopuszczalnych naprężeń dla osi tocznych, które są przedstawione w tabeli 8 i 9.

Zestawienie granic zmęczenia dla stali E1N, EA1T oraz EA4T wg PN-EN 13261:2009 [17]

Tabela 7

\begin{tabular}{|c|c|c|c|c|c|}
\hline Gatunek stali & $\mathbf{F}_{\mathbf{1}}$ & $\mathbf{F}_{\mathbf{2}}$ & $\mathbf{R}_{\mathrm{fL}}$ & $\mathbf{R}_{\mathrm{fE}}$ & $\mathbf{q}=\mathbf{R}_{\mathrm{fL}} / \mathbf{R}_{\mathrm{fE}}$ \\
\hline EA1N & $\geq 200 \mathrm{~N} / \mathrm{mm}^{2}$ & $\geq 80 \mathrm{~N} / \mathrm{mm}^{2}$ & $\geq 250 \mathrm{~N} / \mathrm{mm}^{2}$ & $\geq 170 \mathrm{~N} / \mathrm{mm}^{2}$ & $\leq 1,47$ \\
\hline EA1T & $\geq 200 \mathrm{~N} / \mathrm{mm}^{2}$ & $\geq 80 \mathrm{~N} / \mathrm{mm}^{2}$ & $\geq 250 \mathrm{~N} / \mathrm{mm}^{2}$ & $\geq 170 \mathrm{~N} / \mathrm{mm}^{2}$ & $\leq 1,47$ \\
\hline EA4T & $\geq 240 \mathrm{~N} / \mathrm{mm}^{2}$ & $\geq 96 \mathrm{~N} / \mathrm{mm}^{2}$ & $\geq 350 \mathrm{~N} / \mathrm{mm}^{2}$ & $\geq 215 \mathrm{~N} / \mathrm{mm}$ & $\leq 1,63$ \\
\hline
\end{tabular}

Zestawienie dopuszczalnych naprężeń dla osi tocznych zgodnie z PN-EN 13103:2009 [15]

Tabela 8

\begin{tabular}{|c|c|c|c|c|}
\hline $\begin{array}{c}\text { Gatunek } \\
\text { stali }\end{array}$ & Rodzaj osi & $\begin{array}{c}\text { Wspólczynnik bezpie- } \\
\text { czeństwa }\end{array}$ & Strefa 1 & Strefa 2 \\
\hline EA1N & oś pełna & 1,2 & 166 & 100 \\
\hline EA4T & oś pełna & 1,33 & 180 & 110 \\
\hline
\end{tabular}

Zestawienie dopuszczalnych naprężeń dla tocznych osi drążonych zgodnie z PN-EN 13103:2009 [15]

Tabela 9

\begin{tabular}{|c|c|c|c|c|c|c|}
\hline $\begin{array}{c}\text { Gatunek } \\
\text { stali }\end{array}$ & $\begin{array}{c}\text { Rodzaj } \\
\text { osi }\end{array}$ & $\begin{array}{c}\text { Współczynnik } \\
\text { bezpieczeństwa }\end{array}$ & Strefa 1 & Strefa 2 & Strefa $\mathbf{3}^{\mathbf{3})}$ & Strefa 4) $^{\mathbf{4}}$ \\
\hline EA1N & Oś drążona & 1,2 & 166 & 92 & 78 & 67 \\
\hline EA4T & Oś drążona & 1,33 & 180 & 99 & 85 & 72 \\
\hline
\end{tabular}

1) strefa 1:osadzenie łożysk ślizgowych, strefy przejścia

2) strefa 2: wszystkie osadzenia z wyjatkiem czopów i płaszczyzn osadzania łożysk ślizgowych

$\left.{ }^{3}\right)$ strefa 3: czopy (pod tożyska toczne)

4) strefa 4: otwór drażony

Zestawienie naprężeń dopuszczalnych dla osi trakcyjnych jest przedstawione w tabeli 10 i 11.

Zestawienie dopuszczalnych naprężeń dla osi trakcyjnych zgodnie z PN-EN 13104:2009 [16]

Tabela 10

\begin{tabular}{|c|c|c|c|c|}
\hline Gatunek stali & Rodzaj osi & $\begin{array}{c}\text { Współczynnik bez- } \\
\text { pieczeństwa }\end{array}$ & Strefa 1 & Strefa 2 \\
\hline EA1N & $\begin{array}{c}\text { Oś napędna z wtłoczonym kołem lub } \\
\text { zębnikiem przekładniowym }\end{array}$ & 1,5 & 133 & 80 \\
\hline EA4T & Inne przypadki & 1,3 & 154 & 92 \\
\hline
\end{tabular}


${ }^{1)}$ strefa1:osadzenie tożysk ślizgowych, dna rowków między squsiadujacymi osadzeniami, powierzchnie gumowe, pierścienie uszczelniajace, strefy przejścia

${ }^{2)}$ strefa 2: osadzenia kót, osadzenia tarcz hamulcowych, osadzenia tożysk tocznych, osadzenia zębnika, osadzenia pierścieni uszczelniajacych

Zestawienie dopuszczalnych naprężeń dla osi trakcyjnych drążonych zgodnie z PN-EN 13104:2009 [16]

Tabela 11

\begin{tabular}{|c|c|c|c|c|c|c|}
\hline $\begin{array}{c}\text { Gatunek } \\
\text { stali }\end{array}$ & $\begin{array}{c}\text { Rodzaj } \\
\text { osi }\end{array}$ & $\begin{array}{c}\text { Wspólczynnik } \\
\text { bezpieczeństwa }\end{array}$ & Strefa 1 $^{\text {1) }}$ & Strefa 2 $^{\text {2) }}$ & Strefa 3 $^{\text {3) }}$ & Strefa 4) $^{\text {E) }}$ \\
\hline \multirow{2}{*}{ EA1N } & $\begin{array}{c}\text { Oś napędna z } \\
\text { wtłoczonym kołem } \\
\text { lub zębnikiem } \\
\text { przekładniowym }\end{array}$ & 1,5 & 133 & 73 & 63 & 53 \\
\cline { 2 - 7 } & Inne przypadki & 1,3 & 154 & 85 & 72 & 62 \\
\hline \multirow{2}{*}{ EA4T } & $\begin{array}{c}\text { Oś napędna z } \\
\text { wtłoczonym kołem } \\
\text { lub zębnikiem } \\
\text { przekładniowym }\end{array}$ & 1,66 & 145 & 80 & 68 & 58 \\
\cline { 2 - 7 } & Inne przypadki & 1,44 & 167 & 92 & 78 & 67 \\
\hline
\end{tabular}

\footnotetext{
I) strefa 1: osadzenie łożysk ślizgowych, strefy przejścia

2) strefa 2: wszystkie osadzenia z wyjatkiem czopów i płaszczyzn osadzania łożysk ślizgowych

3) strefa 3: czopy (pod łożyska toczne)

4) strefa 4: otwór drażony
}

\section{Powłoki malarskie}

Jak wynika z obecnych trendów rozwojowych tematyka ochrony antykorozyjnej zestawów kołowych zyskała szczególnie na znaczeniu. Powodem da tego są:

- zmieniający się pogląd, że powłoki malarskie mają takie samo znaczenie konstrukcyjne jak inne części zestawu kołowego, na które jest udzielana gwarancja w zakresie $5 \div 8$ lat

- zmieniająca się polityka utrzymania i konserwacji, co prowadzi do przekonania, że naprawa uszkodzeń powłoki malarskiej może być przeprowadzona tylko podczas napraw głównych, a nie podczas przeglądów okresowych.

Jak wynikało z zebranych dotychczas doświadczeń eksploatacyjnych już po dwóch latach zbierano negatywne doświadczenia dotyczące jakości powłoki malarskiej, której jakość nie odpowiadała oczekiwaniom użytkownika taboru kolejowego.

Zgodnie z zapisem w PN-EN 13103:2009 [15] oraz PN-EN 13104:2009 [16] wartości wytrzymałości zmęczeniowej wartości naprężeń dopuszczalnych przy założeniu współczynników bezpieczeństwa można stosować tylko wtedy, gdy warunki eksploatacyjne zapewniaja prawidłowe zabezpieczenie przed korozją przez cały okres użytkowania osi. W przeciwnym przypadku, kiedy pojawiają się wątpliwości, że zabezpieczenie przed korozją nie będzie skuteczne, to graniczne naprężenia powinny być podzielone przez współczynnik uzgodniony przez projektanta i zamawiającego, uwzględniający utrzymania stosowane przez użytkownika. W związku z powyższym nowe przepisy potraktowały zabezpieczenie antykorozyjne jako istotny element zapewnienia antykorozyjnego.

Osie trakcyjne i toczne powinny być zabezpieczone przed korozją w tych miejscach, w których nie występują żadne części łączone.

Powłoki antykorozyjne można podzielić na cztery klasy:

- klasy 1: osie, które są odporne na korozję atmosferyczną oraz uderzenia mechaniczne

- klasy 2: osie, które są narażone na korozję spowodowaną specjalnymi produktami

- klasy 3: osie, które są narażone na korozję atmosferyczną

- klasy 4: osie, które są narażone na korozję atmosferyczną i których obliczone naprężenia są mniejsze od $60 \%$ naprężeń dopuszczalnych, wymienionych $\mathrm{w}$ tabelach 7, 8, 9 i 10 zgodnie PN-EN 13103:2009 [15] oraz PN-EN 13104:2009 [16].

Własności poszczególnych klas zabezpieczeń antykorozyjnych przedstawiono w tabeli 12 . 


\begin{tabular}{|c|c|c|c|c|}
\hline Wlaściwość & Klasa 1 & Klasa 2 & Klasa 3 & Klasa 4 \\
\hline Grubość powłoki & $\times$ & $\times$ & $\times$ & - \\
\hline Przyczepność powłoki & $\times$ & $\times$ & $\times$ & - \\
\hline Wytrzymałość powłoki & $\times$ & $\times$ & $\times$ & - \\
\hline Odporność na odrywanie & $\times$ & $\times$ & - & - \\
\hline $\begin{array}{c}\text { Odporność na działanie } \\
\text { wody morskiej }\end{array}$ & $\times$ & $\times$ & $\times$ & - \\
\hline $\begin{array}{c}\text { Odporność na działanie } \\
\text { mediów korozyjnych }\end{array}$ & - & $\times$ & $\times$ & - \\
\hline $\begin{array}{c}\text { Odporność na działanie } \\
\text { cyklicznych obciążeń me- } \\
\text { chanicznych }\end{array}$ & $\times$ & & $\times$ & \\
\hline
\end{tabular}

Ochrona przed korozją obowiazuje zarówno dla zestawów kołowych nowo-produkowanych, jak również podlegających naprawie i konserwacji. Jak okazuje się z doświadczeń eksploatacyjnych powierzchnia zestawów kołowych jest narażona na uderzenia mechaniczne np. thucznia, znajdującego się na nawierzchni kolejowej, kawałków lodu w warunkach zimowych, działaniu czynników atmosferycznych, zanieczyszczeń do jakich można zaliczyć olej, smary, żeliwny pył ze wstawek hamulcowych. Klasa 1 ochrony antykorozyjnej jest przewidziana przede wszystkim dla osi pojazdów kolejowych, przeznaczonych do prędkości powyżej $200 \mathrm{~km} / \mathrm{h}, \mathrm{z}$ uwagi na bardzo duże prawdopodobieństwo powstania uszkodzeń mechanicznych. Klasa 2 ochrony antykorozyjnej jest przewidziana dla specjalistycznych pojazdów trakcyjnych, przeznaczonych do oczyszczania i konserwacji nawierzchni kolejowej. Jako powłoki antykorozyjne dla wagonów osobowych $\mathrm{w}$ ostatnich latach proponowano farby na bazie żywic epoksydowych, które charakteryzują się z jednej strony odpornością na działanie czynników chemicznych, natomiast $\mathrm{z}$ drugiej strony pewną odpornością na uderzenia mechaniczne. Grubość powłoki malarskiej tego typu wynosi z reguły $200 \mu \mathrm{m}$. W przypadku wagonów towarowych (w szczególności wyposażonych $\mathrm{w}$ hamulec klockowy) stosuje się jednowarstwową powłokę malarską na bazie żywic alkidowych. Grubość powłoki malarskiej wynosi zwykle $60 \div 100 \mu \mathrm{m}$, w zależności od sposobu jej nanoszenia. Powłoki na bazie żywic epoksydowych oraz żywic alkidowych charakteryzuja się dobrym powiązaniem sieciowym i posiadają dużą przyczepność do materiału rodzimego. Jednak jak wykazują doświadczenia, jednowarstowe powłoki antykorozyjne nie spełniaja warunku odporności powłoki na uderzenia mechaniczne. $\mathrm{Z}$ przeprowadzonych testów wynika, że żadna $\mathrm{z}$ dotychczas badanych powłok malarskich nie może spełnić warunku odporności na uderzenia i przy jednoczesnym spełnieniu własności antykorozyjnych. Dalej okazało się, że jednowarstwowe powłoki malarskie, stosowane $\mathrm{w}$ wagonach towarowych nie spełniaja wymagania dotyczącego odporności przed odrywa- niem. Pewne nadzieje związane sa z nowymi farbami, które zostały określone jako polimer A i polimer B [2]. W przypadku polimeru A chodzi o farbe jednoskładnikową, która utwardza się w wyniku procesu polimeryzacji addycyjnej (poliaddycji). Tzw. czas reakcji wynosi kilka sekund tzn. oś po pokryciu tym środkiem jest gotowa do eksploatacji. Przez polimer B rozumie się system jednoskładnikowy, który jest stosowany w formie spieku. Czas reakcji wynosi podobnie jak w przypadku polimeru A kilka sekund. Jak wynika z doświadczeń przeprowadzonych w Bochumer Verein BVV obydwie powłoki antykorozyjne spełniaja wymagania dotyczące wytrzymałości na uderzenia zgodnie z normą PN-EN 13261:2009 [17]. Problem powłok antykorozyjnych sprowadza się również do spełnienia wymagań dotyczących ochrony środowiska. $\mathrm{Z}$ tego powodu ograniczano stopniowo stosowanie farb bitumicznych, które przed długi czas były stosowane jako klasyczny środek antykorozyjny. Zaletą ich była duża odporność na działanie wysokich temperatur, co znalazło szczególne zastosowanie na części zestawów kołowych narażonych na działanie wysokich temperatur (np. koła z tarczami hamulcowymi). W przypadku wystawania piasty koła, koła zębatego lub jarzma na osi występują ,ukryte zagłębienia", które zgodnie z p.3.2.7 normy PN-EN 13261:2009 [17] należy zabezpieczyć przed korozja. Miejsca te są pokazane przykładowo na rys.5.

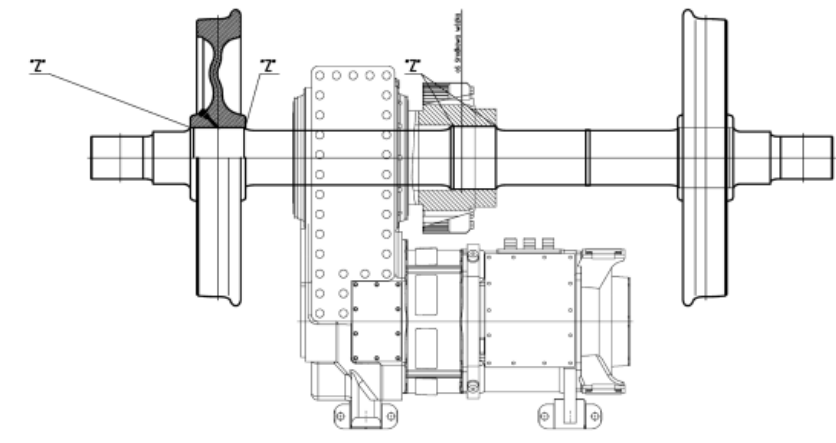

Legenda do rys.5:

Z- „,miejsca ukryte”, które należy zabezpieczać przed korozja

Rys.5. Przykładowe miejsca ukrytych 
Zestawienie własności kleju LOCTITE 5699, jako środka uszczelniającego miejsca ukryte na osi

Tabela 13

\begin{tabular}{|c|c|c|c|}
\hline L.p. & Własność & Wartość & Zakres \\
\hline 1. & Typ chemiczny & $\begin{array}{ll}\text { Oksymowy kauczuk } & \text { silikonowy }\end{array}$ & \\
\hline 2. & Wygląd (barwa) & szary & \\
\hline 3. & Masa właściwa w $20^{\circ} \mathrm{C}$ & 1,45 & \\
\hline 4. & Lepkość w $25^{\circ} \mathrm{C}, \mathrm{mPas}(\mathrm{cP})$ & Pasta tiksotropowa $^{1)}$ & \\
\hline 5. & $\begin{array}{c}\text { Prędkość wyciskania }(\mathrm{gm} / \mathrm{min}) \\
\left(\text { dysza } 3 \mathrm{~mm}, 6 \text { bar, } 25^{\circ} \mathrm{C}\right)\end{array}$ & 250 & $200 \div 550$ \\
\hline 6. & Temperatura zapłonu $(\mathrm{TCC})\left[{ }^{\circ} \mathrm{C}\right]$ & $>93$ & \\
\hline 7. & Twardość, Shore'a & $55 \div 60$ & \\
\hline 8. & Proces utwardzania & $\begin{array}{c}14 \text { dni przy temperaturze } 23 \pm 2^{\circ} \mathrm{C} \text { i } \\
\text { względnej wilgotności powyżej } \\
60 \pm 5 \% \text { oraz szczelinie } 0,5 \mathrm{~mm} \\
\end{array}$ & \\
\hline
\end{tabular}

${ }^{1)}$ Tiksotropia (pamięć cieczy) - własność niektórych rodzajów płynów, w których występuje zależność lepkości od czasu działania sit ścinajacych, które na ten płyn działały. Na przyktad niektóre plyny tiksotropowe moga stać się przez pewien czas mniej lepkie, gdy podda się je intensywnemu mieszaniu. Ptyny takie po pewnym czasie (spoczynku) od momentu mieszania ponownie "zastygaja", tzn. zwiększajq swoja lepkość do normalnej wartości. Możliwe jest jednak także odwrotne zjawisko, tzn. plynem tiksotropowym jest także taka substancja, która czasowo zwiększa swoja lepkość na skutek mieszania. Tiksotropia jest więc procesem odwracalnym; do zniszczenia struktury tiksotropowej płynu wymagane jest dostarczenie energii.

Jako środek zabezpieczający przed korozją stosuje się jednoskładnikowy klej LOCTITE 5699, znany też jako uszczelniacz silikonowy, który wulkanizuje w temperaturze pokojowej (RTV), nie osiada, nie powoduje korozji, ma słaby zapach i zawiera mało części lotnych.

Podstawowe właściwości kleju/uszczelniacza typu Loctite 5699 są przedstawione w tabeli 13.

\section{4. Środki technologiczne zwiększające wytrzyma- lość zmęczeniową osi}

Normy PN-EN 13103:2009 [15] oraz PN-EN 13104:2009 [16] nie uwzględniają zabiegów technologicznych zwiększających wytrzymałość zmęczeniową osi. Metody te można podzielić na trzy rodzaje:

- metody mechaniczne, do których można zaliczyć wałeczkowanie (rolowanie) powierzchni osi

- metody obróbki cieplnej, jak np. hartowanie indukcyjne, hartowanie płomieniowe

- metody cieplno-chemiczne, do których można zaliczyć: utwardzanie dyfuzyjne, azotowanie lub węgloazotowanie [7].

Jak wynika dotychczasowych doświadczeń eksploatacyjnych wytrzymałość zmęczeniowa może być zwiększona o 10 do 150 procent $\mathrm{w}$ stosunku do zakładanej w obliczeniach. Metody mechaniczne, do jakich należą wałeczkowanie (rolowanie) powierzchni polegają na wytworzeniu w warstwie wierzchniej naprężeń ściskających, działających w przeciwnym kierunku niż naprężenia rozciagające od zginania i przyczyniają się do obniżenia naprężeń eksploatacyjnych. W celu zabezpieczenia niezawodnego podwyższenie wytrzymałości zmęczeniowej osi konieczne jest, aby na skutek rolowania uzyskać zwiększoną twardość warstwy powierzchniowej od 25 do $40 \%$, przy czym głębokość warstwy utwardzonego metalu powinna wynosić $0,02 \div 0,04 \mathrm{D}$, gdzie D-średnica wzmacnianego przekroju osi. Przy wyborze parametrów rolowania, szczególnie dla osi drążonych, konieczne jest zachowanie ostrożności, ponieważ przyjęcie zwiększonych naprężeń ściskających na powierzchni może doprowadzić do powstania pęknięcia zmęczeniowego na powierzchni wewnętrznej wydrążenia. $Z$ tego powodu zaleca się, aby dla osi drążonych stosować dolne granice głębokości warstwy utwardzonej tzn. 0,02 średnicy wzmocnionego przekroju osi. Skuteczność zabiegu rolowania powierzchni określa stopień podwyższenia twardości powierzchniowej, który można wyznaczyć z zależności:

$$
\Delta \mathrm{HV}=\frac{\mathrm{HV}_{\mathrm{MAX}}-\mathrm{HV}_{\mathrm{MIN}}}{\mathrm{HV}_{\mathrm{MIN}}}
$$

gdzie:

$\Delta \mathrm{HV}$ - przyrost twardości rolowanej powierzchni osi zestawu kołowego

HVmax - maksymalna twardość na rolowanej powierzchni osi zestawu kołowego

$H_{\text {MIN }}$ - minimalna twardość powierzchni przed rolowaniem osi zestawu kołowego.

Niezbadanym zagadnieniem budzącym wątpliwości jest relaksacja naprężeń w miarę oddziaływania naprężeń eksploatacyjnych, nie mniej jednak gdyby takie zjawisko występowało można wnioskować i tak o cześciowym skompensowaniu skutków działania sił eksploatacyjnych.

Metody obróbki cieplnej zwiększają wytrzymałość zmęczeniową przez zmiany strukturalne $\mathrm{w}$ warstwie wierzchniej, przy czym głównymi parametrami decydującymi o jego skuteczności jest głębokość podgrzanej sceny i prędkość chłodzenia. Metody obróbki cieplno-chemicznej do jakich należą utwardzanie dyfuzyjne, azotowanie lub węgloazotowanie prowadzą 
do zmiany składu chemicznego warstwy wierzchniej. Zmiana składu chemicznego warstwy wierzchniej odbywa się przez dyfuzję węgla lub azotu. Największy udział $\mathrm{w}$ umocnieniu powierzchni $\mathrm{w}$ przypadku utwardzania dyfuzyjnego ma nasycenie warstwy wierzchniej węglem (lub dodatkowo azotem) i ostateczne przemiana w martenzyt. Wskutek tego powstają naprężenia sieciowe, wynikające $\mathrm{z}$ tetragonalnego rozrywania sieci krystalicznej żelaza Do tego dochodzi przy odpowiednim składzie chemicznym stali efekt częściowego umocnienia powierzchniowego wskutek wytrącania się węglików. Azotowanie i węgloazotowanie prowadzą do zwiększenia wytrzymałości przez wnikanie atomów w luki tetragonalne siatki krystalicznej żelaza i tworzenie się azotków żelaza, węgla itd. Właściwości warstwy wierzchniej określa się zasadniczo przez naprężenia własne. Wadą metod obróbki cieplnej jest między innymi widoczny brak poprawy odporności warstwy wierzchniej na korozję. Istotną poprawę odporności warstwy wierzchniej na procesy korozyjne oraz odporności na uderzenia np. thucznia $\mathrm{z}$ nawierzchni kolejowej przynoszą metody obróbki cieplno-chemicznej.

Wraz z wprowadzeniem nowej normy PN-EN 13261:2009 [17] na osie zestawów kołowych pojawił się problem badania naprężeń własnych (p.3.6 niniejszej normy).

W punkcie 3.6 i podpunktach „Naprężenia własne” znajdują się następujące zapisy:

$>$ p.3.6.1 „Postanowienia ogólne: W różnych etapach produkcyjnych nie powinny występować żadne naprężenia własne, które moga prowadzić w eksploatacji do odkształceń osi lub powstania pęknięć zmęczeniowych"

$>$ p.3.6.2. „Dopuszczalne wartości: Największe naprężenia własne na powierzchni osi nie powinny się różnić więcej niż $40 \mathrm{~N} / \mathrm{mm}^{2}$ [40 $\mathrm{MPa}$ pomiędzy dwoma punktami pomiarowymi" (usytuowanie punktów pomiarowych naprężeń własnych w osiach zestawów kołowych jest podane na rys.6)

$>$ p.3.6.3. Metoda pomiarowa; pomiar można przeprowadzić zarówno za pomocą tensometrów jak również promieniowania rentgenowskiego. Metoda ta powinna być uzgodniona pomiędzy producentem a klientem.

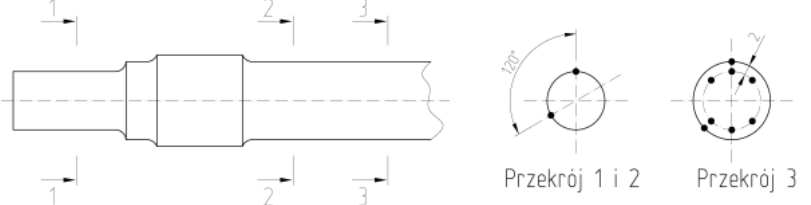

Legenda:

Przekrój 1-1: czop osi zestawu kołowego

Przekrój 2-2: część środkowa osi zestawu kołowego za tzw. „,zapiaściem” Przekrój 3-3: część środkowa osi zestawu kołowego

Punktu pomiarowe sq oznaczone przez ,•”

Rys.6. Usytuowanie punktów pomiarowych
Celem pomiarów naprężeń własnych w osiach zestawów kołowych jest upewnienie się, czy naprężenia własne (szczątkowe) mierzone na głębokości $2 \mathrm{~mm}$ nie przekraczają wartości dopuszczalnej wynoszącej +100 MPa oraz różnica pomiędzy dwoma punktami pomiarowymi nie przekracza $40 \mathrm{MPa}$. Celem tego badania jest stwierdzenie czy na etapie wytwarzania osi (przyjęty proces technologiczny) nie pojawiają się dodatkowe naprężenia rozciągające, które mogą wpływać dodatkowo na wytężenie materiału osi, a ich obecność nie jest uwzględniania w metodyce obliczeniowej przedstawionej w normie PN-EN 13104:2009 [16]. Problem pomiaru naprężeń własnych w osiach zestawów kołowych powstał w wyniku prac Europejskiego Komitetu Normalizacyjnego (fr. Comité Européen de Normalisation) nad edycją normy europejskiej PN-EN 13261:2009 [17]. We wcześniejszych przepisach krajowych tzn. PN-93/K-91045 [18] oraz UIC (unieważniona karta UIC 811-1 [13]) problem pomiaru naprężeń własnych nie był w ogóle poruszany. Oś zestawu kołowego jest obciążona siłami pionowymi, poprzecznymi, hamulcowymi i rozruchowymi, które wywołują zginanie i skręcanie. W wyniku tego oś zestawu kołowego jest obciążona momentem zredukowanym, którego przykładowy wykres jest przedstawiony na rys.7.

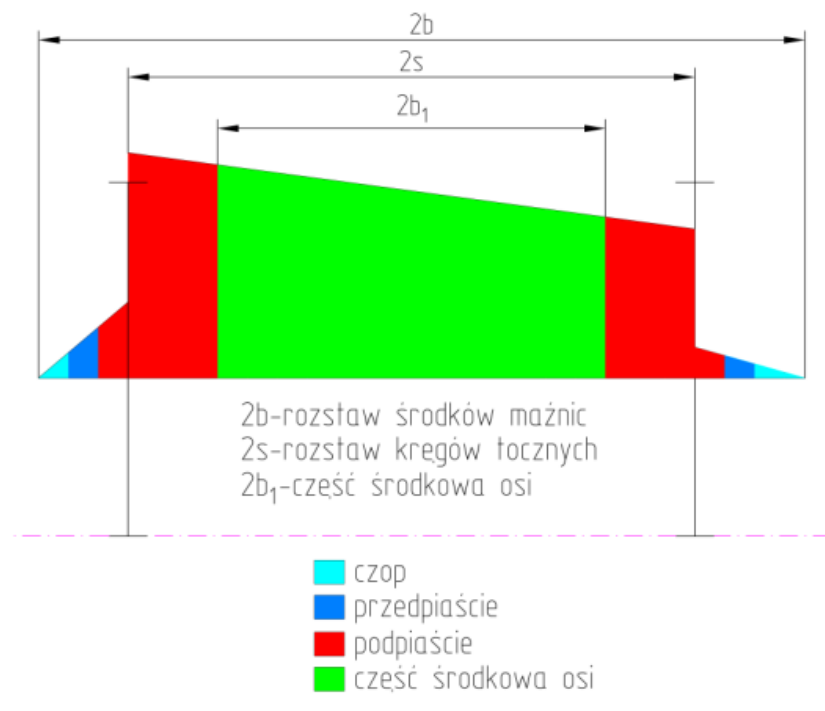

Rys.7. Przykładowy przebieg momentu zredukowanego obciążającego oś zestawu kołowego

W każdym przekroju naprężenia maksymalne obliczane są jako wynik momentu MR, który wynosi:

$$
\mathrm{MR}=\sqrt{\mathrm{MX}^{2}+\mathrm{MY}^{2}+\mathrm{MZ}^{2}}
$$

MR - moment zredukowany (wypadkowy)

MX - moment gnący w płaszczyźnie pionowej

MY - moment gnący w płaszczyźnie poprzecznej

$\mathrm{MZ}$ - moment skręcający.

Moment zredukowany MR wywołuje naprężenia rozciagające $\sigma$, które wyznacza się ze wzoru: 


$$
\sigma=\sigma_{1}-\sigma_{2}=\sqrt{M X^{2}+M Y^{2}+M Z^{2}}
$$

Naprężenia normalne $\sigma_{\mathrm{n}}$ mają następującą wartość (zginana belka o przekroju kołowym):

$$
\sigma_{\mathrm{n}}=\frac{32 \sqrt{\mathrm{MX}^{2}+\mathrm{MY}^{2}}}{\pi \mathrm{d}^{3}}
$$

Wartość naprężeń skręcających lub stycznych $\sigma_{t}$ jest następująca (belka skręcana pomiędzy dwoma przekrojami kołowymi):

$$
\sigma_{\mathrm{t}}=\frac{16 \mathrm{MY}}{\pi \mathrm{d}^{3}}
$$

W wyniku działania momentów sił MX, MY i MZ powstają naprężenia główne $\sigma_{1}$ i $\sigma_{2}$, które wyznacza się odpowiednio ze wzorów:

$$
\sigma_{1}=\frac{\sigma_{\mathrm{n}}+\sqrt{\sigma_{\mathrm{n}}^{2}+4{o_{\mathrm{t}}^{2}}^{2}}}{2}
$$

oraz

$$
\sigma_{2}=\frac{\sigma_{\mathrm{n}}-\sqrt{\sigma_{\mathrm{n}}^{2}+4 \sigma_{\mathrm{t}}^{2}}}{2}
$$

Ponieważ wartość bezwzględna naprężeń głównych jest większa $\sigma_{1}$ i $\sigma_{2}$ (od 10 do 20 razy) niż naprężenia skręcające $\sigma_{t}$ naprężenia zastępcze $\sigma$ dla kontroli przyjętej wartości średnicy „d” wyznacza się ze wg hipotezy koła Mohra zgodnie ze wzorem:

$$
\sigma=\sigma_{1}-\sigma_{2}=\frac{32}{\pi d^{3}} \quad \sqrt{M X^{2}+M Y^{2}+M Z^{2}}
$$

Obliczone naprężenia porównuje się z naprężeniami dopuszczalnymi dla stali E1AN, które wynoszą przykładowo dla pełnych osi trakcyjnych zgodnie z PN-EN 13104:2009 [16]:

$>133 \mathrm{MPa}$ dla strefy 1 tzn. „oś, osadzenia łożysk ślizgowych, na rowków między sąsiadującymi osadzeniami, powierzchnie gumowe, pierścienie uszczelniające, strefy przejścia

$>80 \mathrm{MPa}$ dla strefy 2 tzn. ,osadzenia tarcz hamulcowych, osadzenia łożysk tocznych, osadzenia łożysk tocznych, osadzenia zębnika, osadzenia pierścieni uszczelniających przy zachowaniu współczynnika bezpieczeństwa $S=1,5$ oraz

$>154 \mathrm{MPa}$ dla strefy 1

$>92 \mathrm{MPa}$ dla strefy $2 \mathrm{w}$ pozostałych przypadkach przy zachowaniu współczynnika bezpieczeństwa $S=1,3$.

Ww. naprężenia dopuszczalne są przyjmowane w oparciu o założenie, że przestrzegana jest technologia wykonania osi w zakresie, który jest opisany w PNEN 13261:2009 [17].
Technologia ta musi być zapewniać, aby na etapie:

$>$ wytopu stali

$>$ procesu kucia

$>$ poszczególnych procesów obróbki mechanicznej nie pojawiły się naprężenia własne o wartościach przekraczających kryteria podane w punkcie 3.6 PN-EN 13261:2009 [17].

Naprężenia wewnętrzne, powstające w wyniku procesów technologicznych, głównie obróbki plastycznej i cieplnej można podzielić na trzy kategorie:

$>$ naprężenia pierwszego rodzaju (makronaprężenia); są to naprężenia międzystrefowe $t \mathrm{j}$. powstające między poszczególnymi strefami przekroju i między częściami wyrobu. Im większy jest gradient temperatur na przekroju, jak też gradient pomiędzy poszczególnymi częściami wyrobu (zależy od prędkości i równomierności chłodzenia), naprężenia pierwszego rodzaju przybierają jeszcze większe wartości

$>$ naprężenia wlasne drugiego rodzaju; powstają wewnątrz ziaren lub między ziarnami sąsiadującymi między sobą; przyczyną powstania tych naprężeń są różne współczynniki rozszerzalności liniowej faz występujących w obrabianych wyrobach lub też powstawanie nowych faz o różnej od wyjściowej objętości właściwej

$>$ naprężenia własne trzeciego rodzaju; naprężenia te powstają wewnątrz obszarów nie przekraczających kilku komórek sieci krystalicznej metalu.

Niezależnie od rodzaju występujących naprężeń własnych skutek ich oddziaływania jest jednakowy. Jeżeli ich wielkość przekracza granicę plastyczności materiału, to odkształca się on trwale, natomiast jeżeli wielkość ta przekracza granicę wytrzymałości to materiał pęka. Naprężenia własne, które przekraczają ww. kryteria moga prowadzić do procesów deformacji osi (oś jako element zestawu kołowego posiada bardzo dokładne tolerancje wymiarowe oraz odchyłki kształtu i położenia) w trakcie eksploatacji lub „inicjować pęknięcia zmęczeniowe".

Pomimo tego, że naprężenia własne nie są uwzględnione $\mathrm{w}$ metodyce obliczenia wg normy PN-EN 13104:2009 [16], to można wyjść z założenia że sprawa naprężeń własnych jest ujęta we współczynniku bezpieczeństwa „S”, co powinno zapewnić wystarczający zapas wytrzymałości zmęczeniowej osi zestawu kołowego pojazdu. W związku z tym, że naprężenia szczątkowe mogą posiadać znak dodatni, czyli mieć charakter rozciagający ich wielkość jest ograniczona lokalnie do

+100 MPa. Jak wynika z rys.7 decydujący wpływ na wytężenie osi poosiada moment gnący, w związku z czym rozkład naprężeń w dowolnym przekroju osi jest taki jak przedstawiono na rys.8. 
1)

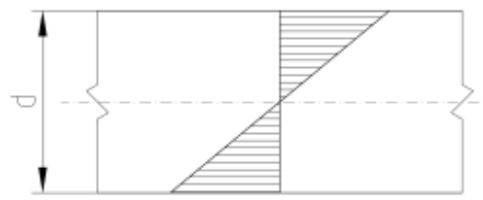

2)

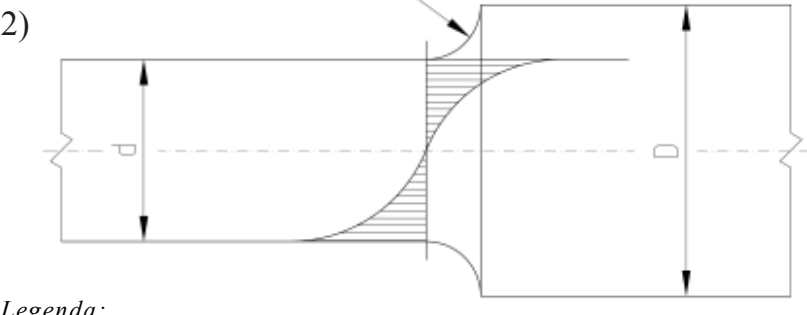

Legenda:

1 - przebieg naprężeń zginajacych w przekroju osi bez karbu

2 - przebieg naprężeń zginajacych w przekroju osi z karbem

Oznaczenia użyte na rysunku.

$d, D$-średnice przekrojów osi zestawu kołowego

$r$ - promień przejściowy pomiędzy przekrojem o średnicy d i przekrojem o średnicy $D$

Rys.8. Rozkład naprężeń w dowolnym przekroju osi zestawu kołowego

\section{Wnioski}

1. Wprowadzenie normy europejskiej PN-EN 13261:2009 [17] ma istotne znaczenie dla technologii wytwarzania osi pojazdów szynowych. Podwyższenie wymogów technologicznych przyczynia się do zwiększenia wytrzymałości zmęczeniowej. Metodyka obliczania osi zestawów kołowych, przedstawiona w PNEN 13103:2009 [15] i PN-EN 13104:2009 [16] ma charakter obligatoryjny pod warunkiem zastosowania stali wymieniowych w PN-EN 13261:2009 [17] wraz z przynależną technologią wykonania, wymaganiami i badaniami. Stosowanie karty UIC 811-1 [13] nie ma już dalej uzasadnienia, zwłaszcza dla nowoprojektowanego i modernizowanego taboru. Stosowanie kryteriów dotyczących reżimu technologicznego zapewnia osiagnięcie minimalnej granicy zmęczenia dla materiałów, wymienionej w normach PN-EN 13103:2009 [15], PN-EN 13104:2009 [16] oraz PN-EN 13261:2009 [17].

2. Jednym $\mathrm{z}$ ważnych osiągnięć nowej normy PN-EN 13261:2009 [17] jest zwrócenie uwagi na jakość powłok malarskich, jako środka konstrukcyjnego zabezpieczającego oś przed skutkami korozji, a tym samym zapewniającym wytrzymałość zmęczeniową osi w czasie wyznaczonego okresu eksploatacyjnego. Jak wynika $\mathrm{z}$ dotychczasowych osiagnięć eksploatacyjnych bardzo duży udział w pęknięciach zmęczeniowych osi zestawów kołowych miał fatalny stan powłoki malarskiej.
3. Opisane wymogi technologiczne przyczyniają się niewątpliwie do wzrostu bezpieczeństwa eksploatowanego taboru pod warunkiem przestrzegania okresów między-kontrolnych w trakcie eksploatacji dla osi zestawów kołowych oraz odpowiednich kwalifikacji personelu wykonującego badania nieniszczące.

4. Do istotnych osiagnięć normy PN-EN 13261:2009 [17] jest podział osi na dwie kategorie tzn. kategorię 1 i kategorię 2. Jako kryterium podziału uznano prędkość pojazdu. Kategoria 1 osi jest przeznaczona dla pojazdów wysokich prędkości powyżej $200 \mathrm{~km} / \mathrm{h}$. W związku z tym wymagania w zakresie zawartości wodoru, czystości struktury mikrograficznej, dopuszczalnych wad materiałowych badanych za pomocą metody ultradźwiękowej i magnetoskopowej są większe aniżeli dla kategorii 2. W dotychczasowych przepisach podział taki nie był wprowadzony. Wdrożenie takiego podziału świadczy o coraz większym udziale transportu kolejowego z wysokimi prędkościami w odniesieniu do całości transportu kolejowego.

\section{Literatura}

[1] Gökcek E., Behrends V.: Automatisches Radsatzmonitoring für Güterwagen. ETR-Eisenbahntechn. Rundsch. Nr.11/2010

[2] Gumbiowski M., Poschmann I., Bowi M., Bardehle T.: Oberfläschenschutz von Radsätzen. Eisenbahningenieur Nr.9/2002.

[3] Engelmann J., Wirtgen J., Nicolin J.: Europäisches Aktionsprogramm für die Güterwagensicherheit. Eisenbahntechn. Rundsch. Nr.11/2010

[4] Hasslinger H.: Lastannahmen für RadsatzwellenBestandsanalyse. Eisenbahntechnische Rundsachau. $\mathrm{Nr} 12,12.2009$.

[5] Liedgens K.: Inspektionskonzept für Radsatzwellen bei der Hamburger Hochbahn. Eisenbahningenieur. $\mathrm{Nr}$ $3 / 2010$.

[6] Malkiewicz T.: Metaloznawstwo stopów żelaza. PWN Warszawa-Kraków. Wydanie III.1976.

[7] Murawa F., Winkler M..: Randschichtbehandelte Radsatzwellen. Eisenbahningenieur Nr.7/2007.

[8] Richard A., Sander M., Wirxel M., Lebehahn J.: Ermittlung von Inspektionsinterwallen mittels Risswachstumsuntersuchungen. Eisenbahningenieur. Luty 2010.

[9] Sobaś M.: Diagnostyka osi zestawów kołowych układów biegowych pojazdów trakcyjnych i tocznych. Pojazdy Szynowe $n r$ 4/2010

[10] Sobaś M: Kryteria obiektywnej oceny prognozowanych stanów osi zestawów osi zestawów kotowych pojazdów trakcyjnych. Pojazdy Szynowe nr 1/2011.

[11]EN 473: Kwalifikacja i certyfikacja personelu do badań nieniszczacych. Ogólne zasady. Marzec 1993.

[12] EN 45013: Ogólne wymagania dotyczqce opinii i akredytacji placówek certyfikujacych (ISO/IEC Tom 61:1996).1998.

[13] Karta UIC 811-1: Warunki techniczne na dostawę osi zestawów kolowych dla pojazdów trakcyjnych $i$ wagonów. 
[14] Karta UIC 960: Kwalifikacja i certyfikacja personelu odpowiedzialnego za prowadzenie badań nieniszczacych elementów zespołów pojazdów szynowych $w$ procesie ich utrzymania.2-gie wydanie z grudnia 2001.

[15]PN-EN 13103:2009: Kolejnictwo. Zestawy kołowe $i$ wózki. Osie zestawów kołowych tocznych. Zasady konstrukcji.

[16]PN-EN 13104:2009: Kolejnictwo. Zestawy kołowe $i$ wózki. Osie zestawów kołowych napędnych. Zasady konstrukcji.

[17]PN-EN 13261:2009: Kolejnictwo. Zestawy kołowe $i$ wózki. Osie. Wymagania dotyczace wyrobu.
[18]PN-93/K-91045: Pojazdy trakcyjne. Osie zestawów kołowych. Wymagania i badania.

[19]Raport ORE/ERRI B136/Rp.11/D: Zestawy kotowe z nasadzanymi tożyskami tocznymi. Konstrukcja, utrzymanie i standaryzacja. Obliczenie osi zestawów kołowych dla wagonów towarowych $i$ osobowych. Utrecht, kwiecień 1979.

[20] OR-9666: „,Diagnostyka układów biegowych pojazdów tocznych i trakcyjnych.” IPS Tabor Wrzesień 2010. 